REVISTA SCIENTIA AGRARIA

Versão On-line ISSN 1983-2443

Versão Impressa ISSN 1519-1125

SA vol. $19 n^{\circ} .1$ Curitiba Jan/Mar 2018 p. 20-27

\title{
PHOTOSYNTHETIC RESPONSE OF TWO MANGO CULTIVARS SUBMITTED TO SALT STRESS AND INFECTED WITH Ceratocystis fimbriata
}

\section{Resposta fotossintética de duas cultivares de manga submetidas ao estresse salino e infectadas por Ceratocystis fimbriata}

Juliana Cristina Vieccelli1; Carlos Eduardo Aucique-Pérez²; Carla Silva Dias³; Dalmo Lopes Siqueira ${ }^{4}$; Fabrício Ávila Rodrigues $^{5 *}$

\author{
${ }^{1}$ Estudante, Departamento de Fitotecnia, Universidade Federal de Viçosa (UFV); jcvieccelli@gmail.com \\ ${ }^{2}$ Estudante, Departamento de Fitopatologia, UFV; carlosaucique@gmail.com \\ 3Estudante, Departamento de Biologia Vegetal, UFV; carla.silva.dias.physiologist@gmail.com \\ 4Professor, Departamento de Fitotecnia, UFV; siqueira@ufv.br \\ 5Professor, Departamento de Fitopatologia, UFV; *autor para correspondência: fabricio@ufv.br
}

Artigo enviado em 30/03/2017, aceito em 04/08/2017 e publicado em 10/04/2018.

\begin{abstract}
This study aimed to investigate the alterations on the photosynthetic performance of mango plants from cultivars Tommy Atkins and Ubá when exposed to salt stresss and infected with Ceratocystis fimbriata. Plants from these two cutivars were grown in plastic pots receiving nutrient solution with 0 and $90 \mathrm{mM} \mathrm{NaCl}$ for 50 days. At 42 days after fungal inoculation, the leaf gas exchange parameters net $\mathrm{CO}_{2}$ assimilation rate $[A]$, stomatal conductance to water vapor $\left[g_{\mathrm{s}}\right]$, internal $\mathrm{CO}_{2}$ concentration $\left[C_{\mathrm{i}}\right]$, and transpiration rate $[\mathrm{E}]$ as well as the lesion length, the upward and the downward relative lesion length and the radial fungal colonization were evaluated. Based on the disease variables evaluated, plants from cultivar Ubá were more resistant to infection by $C$. fimbriata in comparison to plants from cultivar Tommy Atkins. Lower values of $A$ were obtained for plants from cultivar Tommy Atkins submitted to salt stress and infeted with $C$. fimbriata resulting, therefore, in reduced values of $g_{\mathrm{s}}$ and $E$. In general, plants from cultivar Tommy Atkins were more affected at the photosynthetic level in comparison to plants from cultivar Ubá under salt stress and infected with $C$. fimbriata. Under salt stress, stomatal closure reduced the $C_{\mathrm{i}}$ values especially on plants from cultivar Tommy Atkins. Plants from cultivar Tommy Atkins were more susceptible to infection by $C$. fimbriata even when exposed to salt stress.
\end{abstract}

Keywords - Mangifera indica; Photosynthesis; Leaf gas exchange

Resumo - Este estudo investigou as alterações na performance fotossintética de plantas de manga das cultivares Tommy Atkins e Ubá quando expostas ao estresse salino e infectadas com Ceratocystis fimbriata. As plantas dessas duas cultivares foram crescidas em vasos plásticos contendo solução nutritiva com 0 e $90 \mathrm{mM}$ de $\mathrm{NaCl}$ durante 50 dias. Aos 42 dias após inoculação, avaliou-se os parâmetros de trocas gasosas taxa de assimilação líquida de $\mathrm{CO}_{2}[A]$, condutância estomática $\left[g_{\mathrm{s}}\right]$, concentração interna de $\mathrm{CO}_{2}\left[C_{\mathrm{i}}\right]$ e taxa de transpiração $[E]$, bem como o comprimento da lesão no caule, o comprimento relativo da lesão abaixo e acima do ponto de inoculação e a colonização radial do fungo. Baseado nos valores das variáveis relacionadas com a doença, as plantas da cultivar Ubá foram mais resistentes à infecção por C. fimbriata do que as plantas da cultivar Tommy Atkins. Menores valores de $A$ ocorreram para as plantas da cultivar Tommy Atkins submetidas ao estresse salino e infectadas com C. fimbriata resultando, portanto, em reduzidos valores de $g_{\mathrm{s}}$ e E. Em geral, plantas da cultivar Tommy Atkins foram mais afetadas a nível fotossintético em comparação com as plantas da cultivar Ubá submetidas ao estresse salino e infectadas com C. fimbriata. Sob estresse salino, o fechamento estomatal reduziu os valores de $C_{\mathrm{i}}$ especialmente nas plantas da cultivar Tommy Atkins. As plantas da cultivar Tommy Atkins foram mais suscetíveis à infecção por C. fimbriata quando expostas ao estresse salino.

Palavras-chave: Mangifera indica, Fotossíntese; Trocas gasosas 


\section{INTRODUCTION}

Mango (Mangifera indica) is one of the most important tropical fruit cultivated worldwide. Asia is the major mango producer and responsible for $76.4 \%$ of the world production while the remaining $23.6 \%$ is shared by Latin America, Africa countries and Oceania (FAO, 2014). Brazil, with an annual production of about 823,000 tons, is the $9^{\text {th }}$ producer with a share of $3.4 \%$ in the total volume offered (FAO, 2014). The cultivar Tommy Atkins occupies approximately $90 \%$ of the area cultivated with mango in Brazil mainly due to the attractive color and good postharvest characteristics of the fruits. On the other hand, cultivar Ubá is cultivated only in some regions of Brazil, especially in the state of Minas Gerais, and is preferred by the juice industry due to some qualities of the fruits such as high-yield pulp, high soluble-solids, little fiber and maintenance of light yellow color and aroma after processing (ALMEIDA et al., 2001, BENEVIDES et al., 2008; FARAONI; RAMOS; STRINGHETA, 2009).

Mango orchards are often affected by both abiotic and biotic types of stresses and the occurrence of mango wilt, caused by the fungus Ceratocystis fimbriata Ellis \& Halst., and salt stress have greatly affected mango yield and the duration of the orchards (VAN WYK et al., 2011; ZUAZO; RAYA; RUIZ, 2003). Soil salinity has become a serious factor limiting the productivity and quality of several agricultural crops mainly because it affects plant development by reducing plant water potential, altering nutrients uptake, and increasing the accumulation of toxic ions (HASEGAWA et al., 2000; ZHU, 2001). High soil salinity damages approximately $20 \%$ of total irrigated lands worldwide and takes 1.5 million ha out of production each year (MUNNS and TESTER, 2008).

Mango wilt has been reported to occur in many states in Brazil from north to south and constitutes a serious problem for the new mango orchards (ROSSETTO et al., 1996; OLIVEIRA et al., 2016). The fungus $C$. fimbriata extensively colonize the pith parenchyma in stem tissues of mango plants from susceptible cultivars such as Tommy Atkins in comparison to more resistant one such as Ubá in the radial direction; therefore the fungal hyphae reach the xylem vessels and stimulate the formation of intense polysaccharide gels and tyloses (ROSSETTO et al., 1996; ARAUJO et al., 2014). Mango trees submitted to salt stress have the apex and the edges of the leaves burned and in more severe cases plant growth is dramatically reduced following by death of the entire canopy (ZUAZO; RAYA; RUIZ, 2003). Plants from the same species and even from the same cultivar show different responses when exposed to salt stress (NEVES et al.,
2008). In contrast to cultivar Ubá, plants from cultivar Tommy Atkins are more tolerant to salt stress (LUCENA, 2009, MIRISOLA FILHO, 2003). It is well known that plants submitted to abiotic stresses are more predisposed to the occurrence of diseases. According to MATTHEW et al. (2010), the roots of tomato and chrysanthemum plants grown in nutrient culture and exposed to salt stress were more susceptible to infection by Phytophthora spp..

One strategy to evaluate the physiological changes in plants subjected to different types of stresses, including the occurrence of diseases, is the measurement of the leaf gas exchange parameters (BERGER et al., 2007). Photosynthesis is greatly affected by salinity due to damage in the photosynthetic machinery at multiple levels such as pigments, stomatal functioning and gaseous exchange, structure and function of thylakoid membrane, electron transport system and enzymes activities (FARIED, 2016). The effect of soil salinity on plant growth can be direct as indicated by the decrease on $\mathrm{CO}_{2}$ availability caused by diffusion limitations through the stomata and the mesophyll or alterations at the photosynthetic metabolism (FARIED, 2016; LAWLOR and CORNINC, 2002).

Considering the importance of mango wilt to decrease mango yield, this study aimed to investigate the alterations on the photosynthesis of mango plants from two cultivars differing on their basal level of resistance to $C$. fimbriata infection that were submitted to salt stress.

\section{MATERIALS AND METHODS}

\section{Plant material}

Mango plants $(\approx 2$ years old) from cultivars Tommy Atkins and Ubá, moderately resistant and resistant, respectively, to C. fimbriata (ARAUJO et al., 2014) were grown in plastic pots containing $20 \mathrm{~L}$ of washed sand under greenhouse conditions (temperature of $30 \pm 2^{\circ} \mathrm{C}$ and relative humidity of $70 \pm 5 \%$ ). Plants received nutrient solution ( $3 \mathrm{~L}$ per plastic pot) daily prepared as described by HOAGLAND and ARNON (1950) with some modifications as follow: $1.0 \mathrm{mM}$ $\mathrm{KNO}_{3}, 0.25 \mathrm{mM} \mathrm{NH}_{4} \mathrm{H}_{2} \mathrm{PO}_{4}, 0.1 \mathrm{mM} \mathrm{NH}_{4} \mathrm{Cl}, 0.5 \mathrm{mM}$ $\mathrm{MgSO}_{4} \cdot 7 \mathrm{H}_{2} \mathrm{O}, 1.0 \mathrm{mM} \mathrm{Ca}\left(\mathrm{NO}_{3}\right)_{2}, 0.30 \mathrm{mM} \mathrm{CuSO}_{4} \cdot$ $5 \mathrm{H}_{2} \mathrm{O}, 0.33 \mathrm{mM} \mathrm{ZnSO}{ }_{4} \cdot 7 \mathrm{H}_{2} \mathrm{O}, 11.5 \mathrm{mM} \mathrm{H}_{3} \mathrm{BO}_{3}, 3.5$ $\mathrm{mM} \mathrm{MnCl}_{2} \bullet 4 \mathrm{H}_{2} \mathrm{O}, 0.1 \mathrm{mM}\left(\mathrm{NH}_{4}\right)_{6} \mathrm{Mo}_{7} \mathrm{O}_{24} \bullet 4 \mathrm{H}_{2} \mathrm{O}, 25$ $\mathrm{mM} \mathrm{FeSO}_{4} \cdot 7 \mathrm{H}_{2} \mathrm{O}$ and $25 \mathrm{mM}$ EDTA disodium. After 40 days of plants adaptation to the nutrient solution mentioned above, sodium chloride $(\mathrm{NaCl})$ was added to the nutrient solution to obtain the concentration of 90 $\mathrm{mM} \mathrm{NaCl}$. Plants supplied only with nutrient solution served as the control treatment. Plants were grown in the plastic pots receiving nutrient solution with 0 and $90 \mathrm{mM}$ $\mathrm{NaCl}$ for 50 days. In order to maintain the nutrient 
REVISTA SCIENTIA AGRARIA

Versão On-line ISSN 1983-2443

Versão Impressa ISSN 1519-1125

SA vol. $19 n^{\circ} .1$ Curitiba Jan/Mar 2018 p. 20-27

solution stable and to ensure that plants were under salt stress, an initial reading of the electrical conductivity (EC) was taken by using a portable conductivity meter. This initial reading served as a reference for the subsequent readings. The EC was checked weekly and whenever there was depletion equal to or greater than $20 \%$ of the initial electric conductivity, the $\mathrm{pH}$ of the nutrient solution was adjusted to 5.5 by using $\mathrm{HNO}_{3}$ or $\mathrm{KOH}$, both at $0.1 \mathrm{M}$.

\section{Inoculation procedure}

At 50 days after being supplied with nutrient solution containing either 0 or $90 \mathrm{mM} \mathrm{NaCl}$, plants were inoculated with the isolate CEBS15 of C. fimbriata. This isolate was obtained from mango plants collected in the city of Brejo Santo, Ceará State $\left(07^{\circ} 29^{\prime} 34^{\prime \prime} S\right.$, $\left.38^{\circ} 59^{\prime} 06^{\prime \prime} \mathrm{W}\right)$, Brazil, exhibiting mango wilt symptoms. The isolate was preserved according to the Castellani's method (DHINGRA and SINCLAIR, 1995). Plugs of malt extract agar medium containing fungal mycelia were transferred to Petri dishes containing potato dextrose agar (PDA) medium. After 3 days, the PDA plugs containing fungal mycelia were transferred to new Petri dishes containing the same culture medium and maintained in an incubator (temperature of $25^{\circ} \mathrm{C}$ and 12 $\mathrm{h}$ photoperiod) for 14 days. Plants were inoculated according to AL-SADI et al. (2010) with a few modifications (ARAUJO et al., 2014). Stem disks (10 $\mathrm{mm}$ diameter, approximately $2 \mathrm{~mm}$ in depth) were removed from the stems with the aid of a punch at approximately $5 \mathrm{~cm}$ above the graft scar. A PDA plug (10 $\mathrm{mm}$ diameter) obtained from a 14-day-old fungal colony was then placed into the punch hole. Each hole containing a PDA plug with fungal mycelia was covered with a piece of moistened cotton and wrapped with parafilm to maintain adequate moisture for fungal infection. The disks used to inoculate each plant were taken from the middle portion of each fungal colony to ensure that inoculation was as homogeneous as possible. The insertion of plugs of PDA into the holes in the stem of plant served as the control treatment.

\section{Relative lesion indices}

Disease progress was evaluated at 42 days after inoculation (dai). The upward, downward and radial colonization of the stem tissues by fungal hyphae was evaluated by measuring the length (in $\mathrm{mm}$ ) of the internal necrotic tissue using a digital caliper. The upward relative lesion length (URLL) and the downward relative lesion length (DRLL) were determined as the ratio between the length from the graft scar to the top of the stem (LGST) and the lesion length (LL) in the same interval (upward and downward) from the inoculation point according to the following formula: URLL or DRLL = LL 100/LGST. The radial fungal colonization (RFC) was determined as the length of the necrotic tissue in relation to the total stem diameter $\times 100$.

\section{Photosynthetic measurements}

Gas exchange parameters were measured on the first fully expanded leaf, from the base to the top, of each plant of the replication of each treatment at 42 dai. Measurements were conducted under ambient $\mathrm{CO}_{2}(390$ $\pm 10 \mu \mathrm{mol} \mathrm{mol} \mathrm{m}^{-1}$ and temperature conditions with artificial light $\left(1200 \mu \mathrm{mol}\right.$ photons $\mathrm{m}^{-2} \mathrm{~s}^{-1}$ at the leaf level). Net carbon assimilation rate $(A)$, stomatal conductance to water vapour $\left(g_{\mathrm{s}}\right)$, internal $\mathrm{CO}_{2}$ concentration $\left(C_{\mathrm{i}}\right)$ and transpiration rate $(E)$ were measured throughout the morning (0730 to $1200 \mathrm{~h}$ ) using a portable open-system infrared gas analyzer (LCpro model + , Portable Photosynthesis System ADC BioScientific Limited, UK). All of the measurements were performed at $25^{\circ} \mathrm{C}$ and the vapor pressure deficit was maintained at approximately $1.0 \mathrm{kPa}$ while the amount of blue light was set to $10 \%$ of the photosynthetic photon flux density to optimize stomatal aperture.

\section{Statistical analysis}

Two $2 \times 2 \times 2$ factorial experiments (denominated as Experiments 1 and 2), consisting of the factors cultivars (Tommy Atkins and Ubá), plant inoculation (non-inoculated and inoculated plants) and $\mathrm{NaCl}$ doses $(0$ or $90 \mathrm{mM}$ ) were arranged in a completely randomized design with five replications. Each experimental unit consisted of one mango plant per plastic pot. Data from all variables were subjected to analysis of variance (ANOVA). Data from RFC, URLL, DRLL and LL as well as from the four leaf gas exchange parameters from Experiments 1 and 2 were analyzed using the MIXED procedure of the SAS software (Release 8.02 Level 02M0 for Windows, SAS Institute, Inc., 1989, Cary, NC, USA) to determine if data from Experiments 1 and 2 could be combined (MOORE and DIXON, 2015). Data from each variable and parameter were submitted to an analysis of variance (ANOVA) and the treatment means were compared based on the F-test using SAS (version 9.0, SAS Institute Inc., Cary, NC, USA). Pearson correlation was used to determine the relationships among the gas exchange parameters, the $\mathrm{NaCl}$ doses and plant inoculation for each cultivar separately.

\section{RESULTS}

\section{Disease variables}

At least one of the factors cultivars and $\mathrm{NaCl}$ doses was significant for the RFC, URLL and DRLL. The interaction between these factors was significant only for LL. At the dose of $0 \mathrm{mM}$ of $\mathrm{NaCl}$, the RFC, URLL, DRLL and LL significantly increased by 63, 46, 70 and $60 \%$, respectively, for plants from cultivar 

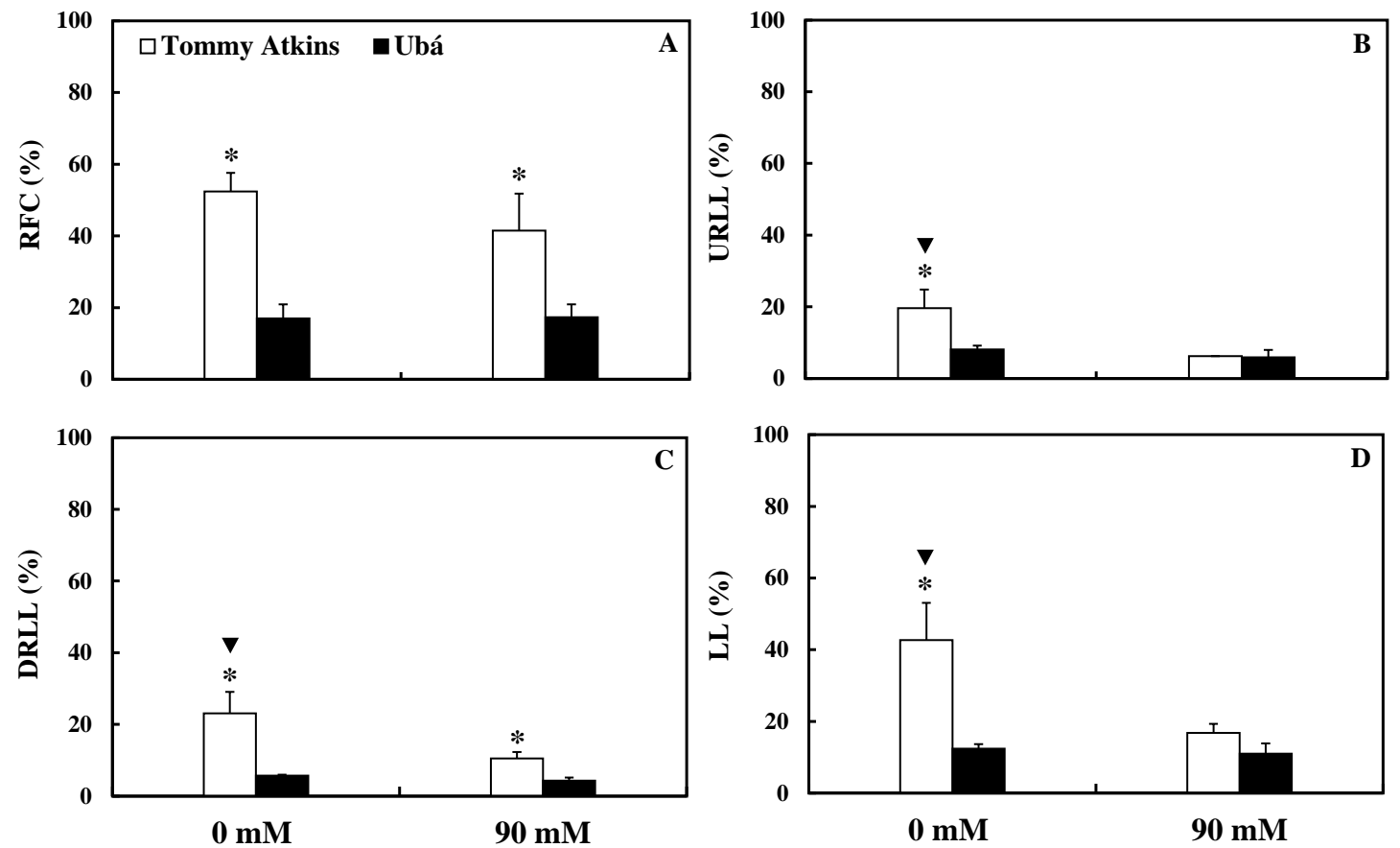

Figure 1- Radial fungal colonization (RFC) (A), upward relative lesion length (URLL) (B), downward relative lesion length (DRLL) (C) and lesion length (LL) (D) determined on the stem tissues of mango plants from cultivars Tommy Atkins and Ubá grown in nutrient solution containing 0 and $90 \mathrm{mM}$ of $\mathrm{NaCl}$ at 42 days after inoculation with Ceratocystis fimbriata. Means of the cultivars Tommy Atkins and Ubá at each $\mathrm{NaCl}$ rate followed by an asterisk $(*)$ are significantly different according to F-test $(P \leq 0.05)$. The symbol $\nabla$ indicates significant difference between the doses of 0 and $90 \mathrm{mM}$ of $\mathrm{NaCl}$ for cultivar Tommy Atkins according to F-test $(P \leq 0.05)$. Bars represent the standard deviation of means. $n=$ 10 .

Tommy Atkins in comparison to plants from cultivar Ubá. At the dose of $90 \mathrm{mM}$ of $\mathrm{NaCl}$, the RFC and DRLL significantly increased by 58 and $60 \%$, respectively, for plants from cultivar Tommy Atkins in comparison to plants from cultivar Ubá. The URLL, DRLL and LL significantly increased by 68,55 and $60 \%$ for plants from cultivar Tommy Atkins grown at the dose of $0 \mathrm{mM} \mathrm{NaCl}$ in comparison to the dose of $90 \mathrm{mM} \mathrm{NaCl}$ (Fig. 1A-D).

\section{Leaf gas exchange parameters}

At least one of the factors cultivars, $\mathrm{NaCl}$ doses and plant inoculation as well as some interactions between these factors were significant for $A, g_{\mathrm{s}}, C_{\mathrm{i}}$ and $E$. For plants from cultivar Tommy Atkins at the dose of $0 \mathrm{mM}$ $\mathrm{NaCl}, A, g_{\mathrm{s}}$ and $E$ significantly decreased by 38,47 and $36 \%$, respectively, for inoculated plants in comparison to non-inoculated ones (Fig. 2A, C and G). For plants from cultivar Ubá at the dose of $0 \mathrm{mM} \mathrm{NaCl}, g_{\mathrm{s}}$ significantly decreased by $27 \%$ for inoculated plants in comparison to non-inoculated ones (Fig. 2D). There were significant increases of 92,47 and $29 \%$ for $A, g_{\mathrm{s}}$ and
E, respectively, for plants from cultivar Tommy Atkins supplied with $0 \mathrm{mM} \mathrm{NaCl}$ in comparison to the dose of $90 \mathrm{mM} \mathrm{NaCl}$ (Fig. 2A, C and G). For cultivar Tommy Atkins, $C_{\mathrm{i}}$ significantly increased by $19 \%$ for plants supplied with $90 \mathrm{mM} \mathrm{NaCl}$ in comparison to the dose of $0 \mathrm{mM} \mathrm{NaCl}$ (Fig. 2E). For plants from cultivar Ubá supplied with the dose of $0 \mathrm{mM} \mathrm{NaCl}, A$ and $C_{\mathrm{i}}$ were significantly higher by 37 and $6 \%$, respectively, in comparison to the dose of $90 \mathrm{mM} \mathrm{NaCl}$ (Fig. 2B and F). At the dose of $0 \mathrm{mM} \mathrm{NaCl}, A, g_{\mathrm{s}}, C_{\mathrm{i}}$ and $E$ significantly decreased by $29,48,15$ and $19 \%$, respectively, for plants from cultivar Tommy Atkins in comparison to plants from cultivar Ubá (Fig. 2A-G). At the dose of $90 \mathrm{mM}$ $\mathrm{NaCl}, A, g_{\mathrm{s}}$ and $E$ significantly decreased by 93,68 and $38 \%$, respectively, for plants from cultivar Tommy Atkins in comparison to plants from cultivar Ubá (Fig. 2A, B, C, D, G and H). For plants from cultivar Tommy Atkins, $C_{\mathrm{i}}$ significantly increased by $8 \%$ in comparison to plants from cultivar Ubá at the dose of $90 \mathrm{mM} \mathrm{NaCl}$ (Fig. 2E and F). 

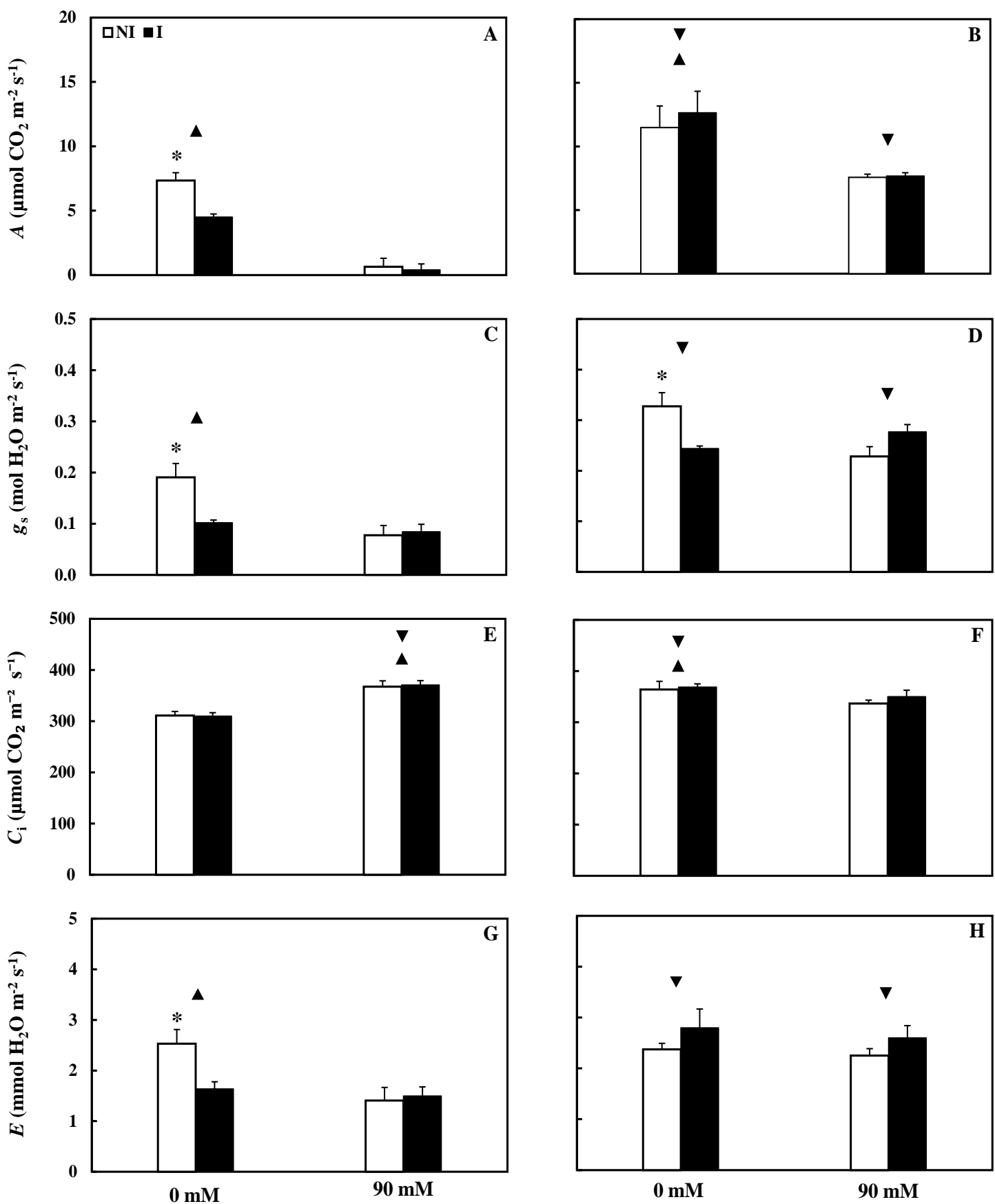

Figure 2- Leaf gas exchange parameters net $\mathrm{CO}_{2}$ assimilation rate $(A)(\mathrm{A}$ and $\mathrm{B})$, stomatal conductance to water vapor $\left(g_{\mathrm{s}}\right)(\mathrm{C}$ and $\mathrm{D})$, internal $\mathrm{CO}_{2}$ concentration $\left(C_{\mathrm{i}}\right)(\mathrm{E}$ and $\mathrm{F})$ and transpiration rate $(E)(\mathrm{G}$ and $\mathrm{H})$ determined on the leaves of mango plants from cultivars Tommy Atkins (A, C, E and $\mathrm{H})$ and Ubá (B, D, F and I) grown in nutrient solution containing 0 and $90 \mathrm{mM}$ of $\mathrm{NaCl}$ and non-inoculated (NI) or inoculated (I) with Ceratocystis fimbriata. For each cultivar and $\mathrm{NaCl}$ dose, means of the $\mathrm{NI}$ and $\mathrm{I}$ treatments indicated by an asterisk $(*)$ are significantly different according to $\mathrm{F}$ test $(P \leq 0.05)$. The symbols $\Delta$ and $\nabla$ indicate significant difference between the doses of 0 and $90 \mathrm{mM}$ of $\mathrm{NaCl}$ and between the cultivars Tommy Atkins and Ubá, respectively, according to F-test $(P \leq 0.05)$. Bars represent the standard deviation of means. $n=10$. 


\section{DISCUSSION}

The present study brings novel information regarding the photosynthetic performance, herein investigated by examining key parameters related to leaf gas exchange, of mango plants from two cultivars previously exposed to salt stress and challenged with $C$. fimbriata.

Based on the variables RFC, URLL, DRLL and LL evaluated, plants from cultivar Ubá were more resistant to mango wilt than plants from cultivar Tommy Atkins. According to ARAUJO et al. (2014, 2015), hyphae of $C$. fimbriata massively colonized the stem tissues of plants from cultivar Tommy Atkin in comparison to cultivar Ubá resulting, therefore, in high disease severity and earlier plant wilt. Indeed, on stem tissues of plants from cultivar Ubá, most of the cells reacted to $C$. fimbriata infection by accumulating phenolic-like material and higher levels of insoluble sulfur and calcium (ARAUJO et al., 2014). Hypothetically, this effect may be associated to a high salt concentration in the stem tissues which may affected the colonization by C. fimbriata. Additionally, the lower transport in the xylem sap flow may reduce a possible dispersion of the pathogen's structures through the vascular tissues and reducing, therefore, the available of water and nutrients necessary for fungal growth. Interestingly, plants from cultivar Tommy Atkins did not have their level of resistance to mango wilt decreased when exposed to salt stress. In the meantime, plants from cultivar Ubá were resistant to mango wilt regardless of being submitted to salt stress. According to Zuazo, Raya e Ruiz (2003), plants from cultivar Tommy Atkins submitted to salt stress showed intense necrosis at both apex and margins of the leaves.

Alterations on the photosynthesis has been reported to occur in several hosts affected by vascular pathogens such as Verticillium dablia on pepper, Fusarium oxysporum f. sp. lycopersici on tomato, lethal yellowing phytoplasma on coconut and $C$. fimbriata on mango (NOGUÉS et al, 2002; MAUST et al, 2003; PASCUAL et al., 2010; BISPO et al., 2016ab). In general, unstressed plants from cultivar Tommy Atkins infected with $C$. fimbriata showed lower values for $A, g_{\mathrm{s}}$ and $E$ and unchanged values for $C_{\mathrm{i}}$ in comparison to non-infected plants. In the meantime, changes in the values for the four leaf gas exchange parameters were minimal when comparing stressed plants non-infected and plants infected with $C$. fimbriata. Overall, $A$ was dramatically reduced for stressed plants regardless of inoculation with

et al., 2014ab; AL-SADI et al., 2010; BISPO et al., 2016ab). The photosynthetic alterations showed for the stressed plants from cultivar Tommy Atkins were possibly resulted from drastic alterations in the vascular system of the infected stems. The remarkable differences between the unstressed plants from the cultivars Tommy Atkins and Ubá regarding their response to $A, g_{\mathrm{s}}$ and $E$
C. fimbriata while the inverse was obtained for $C_{\mathrm{i}}$. For non-infected and unstressed plants, the values for $g_{\mathrm{s}}$ and $E$ were greater in comparison to the stressed ones. By contrast, changes on $g_{\mathrm{s}}$ and $E$ were almost imperceptible. Generally, both unstressed and stressed plants from cultivar Ubá experienced less changes on the values of $A, g_{\mathrm{s}}, C_{\mathrm{i}}$ and $E$ regardless of whether they were challenged with $C$. fimbriata. However, stressed plants showed greater values for $A$ and $C_{\mathrm{i}}$ regardless of being inoculated with $C$. fimbriata. By contrast, $g_{\mathrm{s}}$ values were greater for stressed inoculated plants in contrast to the nonstressed and non-inoculated ones. Changes on $E$ between nonstressed and stressed plants were imperceptible. Unexpectedly, the stressed non-infected plants from cultivar Tommy Atkins in contrast to the stressed infected counterparts were not favored in terms of stomatal opening that possibly resulted in increases in both $A$ and $E$. There were progressive decreases in $A, g_{s}$ and $E$ for the nonstressed infected plants from cultivar Tommy Atkins being the magnitude of the reduction quite imperceptible for stressed infected plants. However, despite the reduced stomatal aperture, which should reduce the $\mathrm{CO}_{2}$ influx, the $C_{\mathrm{i}}$ values did not change for nonstressed or stressed plants from cultivar Tommy Atkins regardless of inoculation with $C$. fimbriata. Reductions in $E$ for the nonstressed plants from cultivar Tommy Atkins infected with $C$. fimbriata can be linked to both reductions in $g_{s}$ and stomatal closure. In the present study, plants from cultivar Ubá showed higher values of $E$ than plants from cultivar Tommy Atkins suggesting, therefore, a better efficiency of using water these plants that suffer water deprivation. Concomitant reductions in both $E$ and $g_{\mathrm{s}}$ have been also reported to occur for the the mango- $C$. fimbriata interaction (BISPO et al., 2016ab). Plants submitted to a high salt concentration had their stomatal opening alterated due to an increase in the resistance to $\mathrm{CO}_{2}$ diffusion and interference in the leaf tissue hydration as well as on the dissipation of light energy necessary for $\mathrm{CO}_{2}$ fixation (FLEXAS et al., 2008). Plants from the mango cultivars Haden and Palmer showed a linear decrease in the $g_{\mathrm{s}}$ values when exposed to an increase in $\mathrm{NaCl}$ concentration in contrast to plants from cultivars Tommy Atkins and Ubá (LUCENA, 2009).

It is known that vascular pathogens, as for example C. fimbriata, by massively colonizing the vascular vessels end up disrupting the transport of water, solutes and minerals which culminated in wilted leaves, intense necrosis of the stem tissue and alterations in photosynthesis as the result of a state of induction of water stress or stomatal closure (ARAUJO

is plausible to be associated with their physiological variability to these parameters. According to IYER and DEGANI (1997), there is a great genetic variability among mango cultivars regarding their agronomic and physiological traits. It is important to point out that the reduced mango wilt symptoms, based on the lower values for RFC, URLL, DRLL and LL, for stressed 
plants from cultivar Tommy Atkin suggest that factors associated with damage to the stem tissue caused by the excess of chloride ion indirectly affected the colonization of the stem tissue by $C$. fimbriata. It is known that plants submitted to conditions of salt stress show changes in the structural properties of their cell wall and have water permeability of the plasma membrane lowered besides alterations on the stomatal opening that lead to an increase in the resistance to $\mathrm{CO}_{2}$ diffusion (IRAKI et al., 1989; FLEXAS et al., 2008; CHAVES; FLEXAS; PINHEIRO, 2009).

\section{CONCLUSIONS}

Plants from cultivar Ubá were more resistant to mango wilt in comparison to plants from cultivar Tommy Atkins. In general, plants from cultivar Tommy Atkins were more affected at the photosynthetic level in

\section{REFERENCES}

ALMEIDA, C. O.; SOUZA, J. S.; MENDES, L. N.; PEREIRA, R. J. Tendências do mercado internacional de manga. Revista Econômica do Nordeste, v. 32, p. 112-20, 2001.

AL-SADI, M.; AL-OUWEISI, A.; AL-SHARIANI, K.; AL-ADAWI, A. O.; KAPLAN, E.; DEADMAN, J. Histological changes in mango seedlings following infection with Ceratocystis manginecans, the cause of mango decline. Journal of Phytopathology, v. 158, p. 738-743, 2010.

ARAUJO, L.; BISPO, W. M. S.; CACIQUE, I. S.; MOREIRA, W. R.; RODRIGUES, F. A. Resistance in mango against infection by Ceratocystis fimbriata. Phytopathology, v. 104, p. 820-833, 2014a.

ARAÚJO, L.; BISPO, W. M. S.; CRUZ, M. F. A.; RODRIGUES, F. A. Histopathological aspects of mango resistance to the infection process of Ceratocystis fimbriata. Plant Pathology, v. 104, p. 820833, 2014b.

BENEVIDES, S. D.; RAMOS, A. M.; STRINGHETA, P. C.; CASTRO, V. C. Qualidade da manga e polpa da manga Ubá. Ciência e Tecnologia de Alimentos, v. 28, p. 571-578, 2008.

CHAVES, M. M.; FlEXAS, J.; PINHEIRO, C. Photosynthesis under drought and salt stress: regulation mechanisms from whole plant to cell. Annals of Botany, v. 103, p. 551-560, 2009. comparison to plants from cultivar Ubá under both salt stress and fungal infection. Plants from cultivar Tommy Atkins were more susceptible to mango wilt even when exposed to salt stress. Under salt stress, stomatal closure limited carbon fixation especially on plants from cultivar Tommy Atkins. For instance, the findings from the present study may be of direct relevance to regions where C. fimbriata is endemic and salt concentration in the soil is quite high.

\section{ACKNOWLEDGMENTS}

Professors F. A. Rodrigues and D. L. Siqueira thank the CNPq for their research fellowships. The authors thank Prof. A. C. Alfenas and Dr. L. S. S. Oliveira for kindly providing the isolate of $C$. fimbriata used in this study. This study was supported by a grant from Vale S.A. to Prof. D. L. Siqueira.

DHINGRA, O. D.; SINCLAIR, J. B. Basic Plant Pathology Methods. Boca Raton, FL, USA: Lewis Publisher, 1995.

FAO. 2017.

http://www.fao.org/faostat/en/\#data/QC.

Consulta realizada em 04/08/2017.

FARAONI, A. S.; RAMOS, A. M.; STRINGHETA, P. C. Caracterização da manga orgânica cultivar Ubá. Revista Brasileira de Produtos Agroindustriais, v. 11, p. 9-14, 2009.

FARIED, H. N.; AYYUB, C. M.; AMJAD, M.; ALMED, R. Salinity impairs ionic physiological and biochemical attributes in potato. Pakistan Journal of Agricultural Sciences, v. 53, p. 17-25, 2016.

FLEXAS, J.; RIBAS-CARBÓ, M.; DIAZ-ESPEJO, A.; GALMÉS, J.; MEDRANO, H. Mesophyll conductance to $\mathrm{CO}_{2}$ : current knowledge and future prospects. Plant, Cell \& Environment, v. 31, p. 602621, 2008.

HASEGAWA, P. M.; BRESSAN, S. A.; ZHU, J. K.; BOHNERT, H. J. Plant cellular and molecular responses to high salinity. Annual Review of Plant Physiology and Plant Molecular Biology, v. 51, p. 463-499, 2000.

HOAGLAND, D.; ARNON, D. I. The water culture method for growing plants without soil. California Agriculture Experimental Station Circular. 347 p., 1950. 
IRAKI, N.; BRESSAN, R.; HASEGAWA, P.; CARPITA, N. Alteration of physical and chemical structure of the primary cell wall of growth-limited plant cells adapted to osmotic stress. Plant Physiology, v. 91, p. 29-47, 1989.

IYER, C. P. A.; DEGANI, C. Classical Breeding and Genetics. In: LITZ, R. E. (Ed.). The Mango: Botany, Production and Uses. New York: CAB International. p. 49-68, 1997.

LAWLOR, D. W.; CORNIC, G. Photosynthetic carbon assimilation and associated metabolism in relation to water deficits in higher plants. Plant, Cell \& Environment, v. 25, p. 275-294, 2002.

LUCENA, C. C. Crescimento vegetativo, absorção de nutrientes e trocas gasosas em mangueiras submetidas a estresse salino. 2009. $116 \mathrm{f}$. Dissertação (Mestrado em Fitotecnia) Universidade Federal de Viçosa, Viçosa, MG.

MATTHEW, V. D.; MATTHEW, F. P.; TATIANA, V. R.; JOHN, M. D.; JAMES, D. M.; DAVID, M. R.; RICHARD, M. B. Abscisic acid in salt stress predisposition to Phytophthora root and crown rot in tomato and chrysanthemum. Phytopathology, v. 100, p. 871-879, 2010.

MAUST, B. E.; ESPADAS, F.; TALAVERA, C.; AGUILAR, M.; SANTAMARÍA, J. M.; OROPEZA, C. Changes in carbohydrate metabolism in coconut palms infected with the lethal yellowing phytoplasma. Phytopathology, v. 93, p. 976-981, 2003.

MIRISOLA FILHO, L. A. Tolerância de sete variedades de mangueiras ao estresse salino. 2003. 129 f. Tese (Doutorado em Fitotecnia) Universidade Federal de Viçosa, Viçosa, MG.

MOORE, K. J.; DIXON, P. M. Analysis of combined experiments revisited. Agronomy Journal, v. 107, p. 763-771, 2015.

MUNNS, R., TESTER, M. Mechanisms of salinity tolerance. Annual Review of Plant Biology, v. 59, p. 651681, 2008.
NOGUÉS, S.; COTXARRERA, L.; ALEGRE, L.; TRILLAS, M. I. Limitations to photosynthesis in tomato leaves induced by Fusarium wilt. New Phytologist, v. 154, p. 461-470. 2002.

OLIVEIRA, L. S. S.; DAMACENA, M. B.; GUIMARÃES, L. M. S.; SIQUEIRA, D. L.; ALFENAS, A. A. Ceratocystis fimbriata isolates on Mangifera indica have different levels of aggressiveness. European Journal of Plant Pathology, v. 145, p. 847-856, 2016.

PASCUAL, I.; AZCONA, I.; MORALES, F.; AGUIRREOLEA, J.; SÁNCHEZ-DÍAZ, M. Photosynthetic response of pepper plants to wilt induced by Verticillium dabliae and soil water deficit. Journal of Plant Physiology, v. 167, p. 701-708, 2010.

ROSSETO, C. J.; RIBEIRO, I. J. A.; IGUE, T.; GALLO, P. B. Seca da mangueira: XV, Resistência varietal a dois isolados de Ceratocystis fimbriata. Bragantia, v. 55, p. 117-121, 1996.

VAN WYK, M.; WINGFIELD, B. D.; ALADAWI, A. O.; ROSSETO, C. J.; ITO, M. F.; WINGFIELD, M. J. Two new Ceratocystis species associated with mango disease in Brasil. Mycotaxon, v. 117, p. 381-404, 2011.

WILKA, M. S.; ARAUJO, L.; ÁVILA, R. T.; DaMATTA, F. M.; RODRIGUES, F. A. Mango resistance against Ceratocystis fimbriata is impaired by local starch mobilization. Tropical Plant Pathology, v. 41, p. 225-236, 2016 .

WILKA, M. S.; ARAUJO, L.; CACIQUE, I. S.; DaMATTA, F. M.; RODRIGUES, F. A. Photosynthesis impairments precede noticeable changes in leaf water status of mango plants infected by Ceratocystis fimbriata. European Journal of Plant Pathology, v. 146, p. 419-432, 2016b.

ZHU, J. K. Salt and drought stress signal transduction in plants. Annual Review of Plant Physiology and Plant Molecular Biology, v. 53, p. 247-273, 2002.

ZUAZO, V. H. D.; RAYA, A. M.; RUIZ, J. A. Salt tolerance of mango rootstocks (Magnifera indica $\mathrm{L}$. cv. Osteen). Spanish Journal of Agricultural Research, v. 1, p. 67-78, 2003. 